\title{
Translocation of particles and inflammatory responses after exposure to fine particles and nanoparticles in an epithelial airway model
}

\author{
Barbara Rothen-Rutishauser*, Christian Mühlfeld, Fabian Blank, \\ Claudia Musso and Peter Gehr
}

Address: Institute for Anatomy, Division of Histology, University of Bern, Bern, Switzerland

Email: Barbara Rothen-Rutishauser* - rothen@ana.unibe.ch; Christian Mühlfeld - muehlfeld@ana.unibe.ch;

Fabian Blank - blank@ana.unibe.ch; Claudia Musso - claudia.musso@bluewin.ch; Peter Gehr - gehr@ana.unibe.ch

* Corresponding author

Published: 25 September 2007

Particle and Fibre Toxicology 2007, 4:9 doi:10.1186/1743-8977-4-9
Received: 27 April 2007

Accepted: 25 September 2007

This article is available from: http://www.particleandfibretoxicology.com/content/4/I/9

(C) 2007 Rothen-Rutishauser et al; licensee BioMed Central Ltd.

This is an Open Access article distributed under the terms of the Creative Commons Attribution License (http://creativecommons.org/licenses/by/2.0), which permits unrestricted use, distribution, and reproduction in any medium, provided the original work is properly cited.

\begin{abstract}
Background: Experimental studies provide evidence that inhaled nanoparticles may translocate over the airspace epithelium and cause increased cellular inflammation. Little is known, however, about the dependence of particle size or material on translocation characteristics, inflammatory response and intracellular localization.
\end{abstract}

Results: Using a triple cell co-culture model of the human airway wall composed of epithelial cells, macrophages and dendritic cells we quantified the entering of fine $(1 \mu \mathrm{m})$ and nano-sized $(0.078$ $\mu \mathrm{m})$ polystyrene particles by laser scanning microscopy. The number distribution of particles within the cell types was significantly different between fine and nano-sized particles suggesting different translocation characteristics. Analysis of the intracellular localization of gold $(0.025 \mu \mathrm{m})$ and titanium dioxide $(0.02-0.03 \mu \mathrm{m})$ nanoparticles by energy filtering transmission electron microscopy showed differences in intracellular localization depending on particle composition. Titanium dioxide nanoparticles were detected as single particles without membranes as well as in membrane-bound agglomerations. Gold nanoparticles were found inside the cells as free particles only. The potential of the different particle types (different sizes and different materials) to induce a cellular response was determined by measurements of the tumour necrosis factor- $\alpha$ in the supernatants. We measured a 2-3 fold increase of tumour necrosis factor- $\alpha$ in the supernatants after applying I $\mu \mathrm{m}$ polystyrene particles, gold nanoparticles, but not with polystyrene and titanium dioxide nanoparticles.

Conclusion: Quantitative laser scanning microscopy provided evidence that the translocation and entering characteristics of particles are size-dependent. Energy filtering transmission electron microscopy showed that the intracellular localization of nanoparticles depends on the particle material. Both particle size and material affect the cellular responses to particle exposure as measured by the generation of tumour necrosis factor- $\alpha$. 


\section{Background}

Besides the generation of ultrafine particles from combustion processes (UFP), an increasing number of manufactured nanoparticles (NP), defined as structures with a diameter of 1-100 $\mathrm{nm}$, are released into air, water and soil $[1,2]$. Manufactured NP have many novel applications, thus furthering the progress of nanotechnology [3]. One aim of nanotechnology is to deliver therapeutic and diagnostic agents and is referred to as nanomedicine [4]. NP are already present in many products, such as suncream, other cosmetics or leisure wear [5], and human exposure to NP is strongly increasing.

Upon inhalation, airborne UFP or NP come into contact with a series of structural and functional barriers that protect the respiratory system against harmful and innocuous particulate material [6]. This is important as the internal surface area of the lungs is vast (alveoli and airways approximately $140 \mathrm{~m}^{2}$ ) [7] facilitating efficient access to the lung tissue. However, despite the existence of these barriers, respiratory diseases related to inhalation of airborne UFP are frequent and increasing [8-10]. The physiological barriers of the respiratory system may not be effective to protect the body from particles $<0.1 \mu \mathrm{m}$ in size. Deposition as well as the subsequent fate of inhaled UFP and NP is different from that of larger particles. It has been shown that titanium dioxide $\left(\mathrm{TiO}_{2}\right)$ particles with a diameter of less than $0.1 \mu \mathrm{m}$ are able to cross cellular membranes in a rat lung exposure model that did not involve commonly known phagocytotic mechanisms [11], and that a small fraction of $\mathrm{TiO}_{2} \mathrm{NP}$ are rapidly transported from the airway lumen to the connective tissue and subsequently released into the systemic circulation [12]. As these particles were also found inside pulmonary capillary erythrocytes it is not surprising that in other studies UFP could be localized in many other organs of the body, including the liver, the heart and the nervous system within a few hours after deposition in the respiratory system [13-15]. Once inside the organism ambient particulate matter may cause adverse health effects due to increased pulmonary and cardiovascular morbidity as shown by a number of epidemiological studies $[8,10,16,17]$. In this context, a specific toxicological effect has been attributed to UFP recently [18]. It has been described that inhaled combustion-derived UFP provoke oxidative stress causing inflammation as well as oxidative adducts in the epithelium that may contribute to carcinogenesis [19]. A growing body of literature supports the concept that manufactured NP share the toxic potential of UFP and it is generally accepted that the toxicity of NP depends on a variety of their properties $[20,21]$, such as size [22], bulk material, surface charge [23].

NP have the capacity to enter different cell types and evade endocytotic pathways $[11,24,25]$. In vitro experiments revealed penetration of NP into mitochondria of macrophages and epithelial cells, associated with oxidative stress and mitochondrial damage [26]. In addition, penetration of NP into the nucleus has been shown in a number of studies [11,27-29]. Once inside the cells, NP may cause several biological responses including the enhanced expression of pro-inflammatory cytokines [30], the generation of reactive oxygen species [31] and DNA strand breaks [32]. Further associations between oxidative stress and inflammation responses are described in the literature $[19,33,34]$ and inflammation responses are associated again with adverse health effects $[35,36]$.

In order to determine the importance of particle size and material on the translocation behaviour of NP and their potential to induce cellular responses we have used a triple cell co-culture model of the airway wall composed of monocyte derived macrophages (MDM), epithelial cells and monocyte derived dendritic cells (MDDC) [37]. First, the intracellular localization of fluorescently labeled polystyrene fine particles $(1 \mu \mathrm{m})$ and NP $(0.078 \mu \mathrm{m})$ within the different cell types was analyzed by laser scanning microscopy (LSM) combined with digital image restoration. The quantitative distribution of the different particles among the different cell types was compared using a contingency table analysis. Second, the intracellular localization of NP made of different materials (gold, and $\mathrm{TiO}_{2}$ ) was studied using energy filtering transmission electron microscopy (EFTEM). $\mathrm{TiO}_{2}$ NP were among the earliest industrially produced and applied NP in everyday applications [5]. Gold NP are in use for optical, electronic, magnetic, catalytic, and biomedical applications [38]. Finally, the potential of the particles to induce a proinflammatory response in dependence on size and material was investigated by measurement of the tumor necrosis factor alpha (TNF- $\alpha)$.

\section{Results \\ Translocation of polystyrene fine particles and nanoparticles}

In order to compare the entering and translocation of fine particles and NP into cells of the airway epithelial barrier the interaction of fluorescently labelled polystyrene particles of two different sizes $(1 \mu \mathrm{m}$, and $0.078 \mu \mathrm{m})$ with the cells of the triple cell co-culture system was studied by LSM in combination with immunofluorescence methods and digital image restoration. After incubation with particles for $24 \mathrm{~h}$, cells were fixed and stained for F-Actin in addition to the labelling of specific surface markers, CD14 for MDM, and CD86 for MDDC. MDM and MDDC were filled with $1 \mu \mathrm{m}$ particles, and only few of these particles were detected in epithelial cells (Fig. 1). By applying a deconvolution algorithm even NP, i.e. $0.078 \mu \mathrm{m}$ polystyrene particles, could be visualized and we found many 


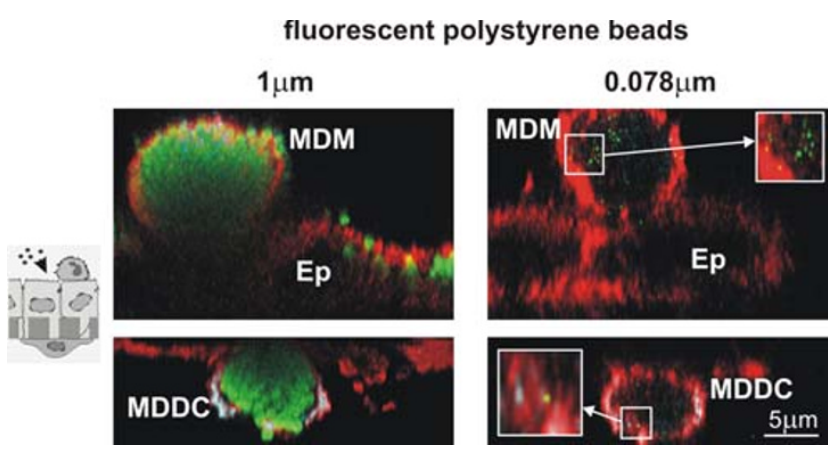

Figure I

Intracellular particle localisation in tripe cell co-cultures visualised by LSM. Cells at the upper side of the insert (upper row) were stained for CDI4 (MDM, turquoise) and F-Actin (all cells, red); cells at the lower side (lower row) for CD86 (MDDC, turquoise) and F-Actin (all cells, red). Fluorescently labelled polystyrene particles (I $\mu \mathrm{m}$, and $0.078 \mu \mathrm{m})$ are shown in green. MDM and MDDC were filled with particles, considerably fewer particles were found in epithelial cells (Ep). All images represent xz-projections.

particles in MDM as well as in MDDC, and again only few particles in epithelial cells (Fig. 1).

Special attention was paid to the integrity of the epithelial layer. Transepithelial electrical resistance (TEER) measurements were performed before and at various times during incubation with the particles. Addition of particles did not influence the integrity of the tight junctions when compared to control cultures and TEER values within a range from 140 to $190 \Omega \mathrm{cm}^{2}$ in the control cultures and in cultures treated with particles were measured.

\section{Quantitative analysis of intracellular polystyrene fine particles and nanoparticles}

Since we had seen a qualitative difference in the number of intracellular particles within the different cell types, the number of fluorescently labeled polystyrene particles of different sizes $(1 \mu \mathrm{m}$, and $0.078 \mu \mathrm{m})$ was counted using a specific software, called "DiaCount", which allows to precisely and reliably count thousands of objects in 3D image stacks created by LSM. As for $1 \mu \mathrm{m}$ particles we found 190 \pm 90 (SD) particles in MDM, $116 \pm 41$ particles in MDDC, and $15 \pm 12$ particles in epithelial cells (Fig. 2). For 0.078 $\mu \mathrm{m}$ particles we found: $177 \pm 90$ particles in MDM, $41 \pm$ 55 particles in MDDC, and $4 \pm 4$ particles in epithelial cells (Fig. 2).

\section{Contingency table analysis for polystyrene fine particles and nanoparticles (Table I)}

With 3-1 compartments (cell types) times 2-1 groups (differently sized particles $)=2$ degrees of freedom, and a total

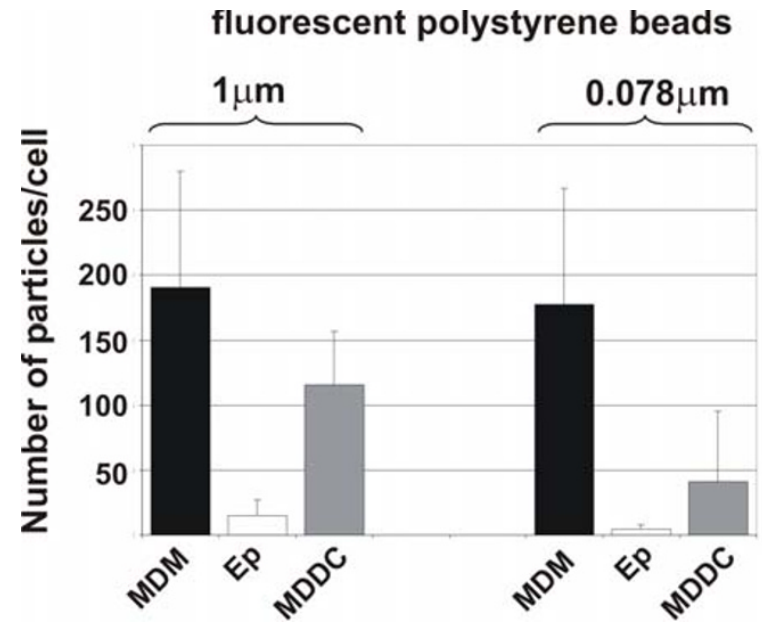

Figure 2

Quantification of particles inside individual cells. Intracellular particle numbers were analysed in cultures exposed to I $\mu \mathrm{m}$, and $0.078 \mu \mathrm{m}$ polystyrene particles with the software Diacount. Epithelial cells (Ep). Number of intracellular particles was counted in individual cells. Data are expressed as the mean of 3-4 experiments ( $10-14$ cells scanned per experiment by LSM).

chi squared value of 24.83 the null-hypothesis that the differently sized particles are similarly distributed among the different cells has to be rejected $(\mathrm{p}<0.01)$. The partial chi-squared value contributed $10 \%$ or more to the total chi-squared for both particle sizes in macrophages and MDDC. For $1 \mu \mathrm{m}$ particles there were fewer particles than expected in macrophages and more particles than expected in MDDC. In contrast, for $0.078 \mu \mathrm{m}$ particles, there were more particles than expected in MDM and fewer particles than expected in MDDC.

\section{Intracellular localisation of differently composed nanoparticles}

In order to analyse whether the material of the NP determines its intracellular localization, $\mathrm{TiO}_{2} \mathrm{NP}$ (mean diameter of $0.032 \mu \mathrm{m}$ ) and colloidal gold NP (diameter of 0.025 $\mu \mathrm{m})$ were visualized and analysed in cells using EFTEM [25]

Bigger membrane-bound aggregates $(>0.2 \mu \mathrm{m})$ of $\mathrm{TiO}_{2} \mathrm{NP}$ were identified by analytical TEM in all cell types, i.e. MDM, epithelial cells and MDDC (Fig. 3A). In addition we found single particles and smaller $(<0.2 \mu \mathrm{m})$ aggregates that were not membrane bound (Fig. 3A). Interestingly, silver enhanced gold particles were not observed in vesicles they were only detected as single particles or as small aggregates $(<0.1 \mu \mathrm{m})$ free in the cytoplasm (Fig. 3B). 
A

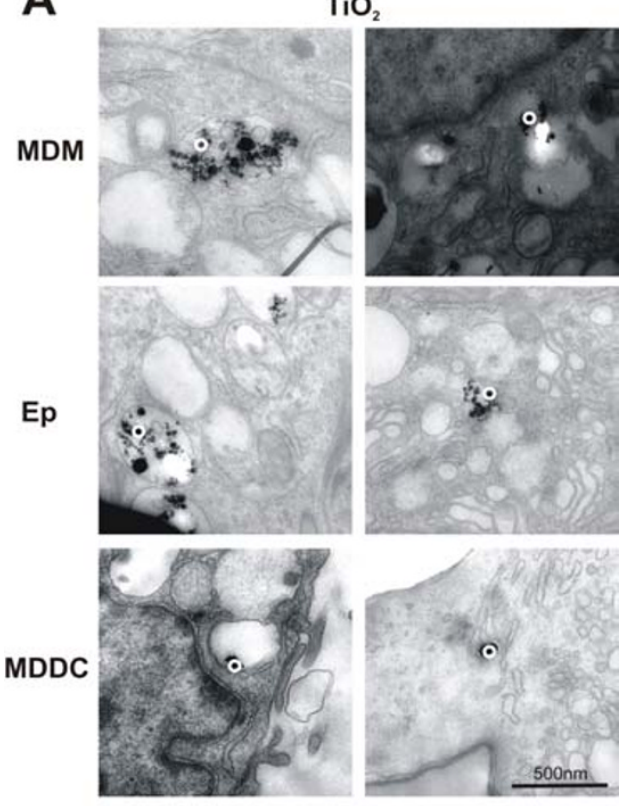

B

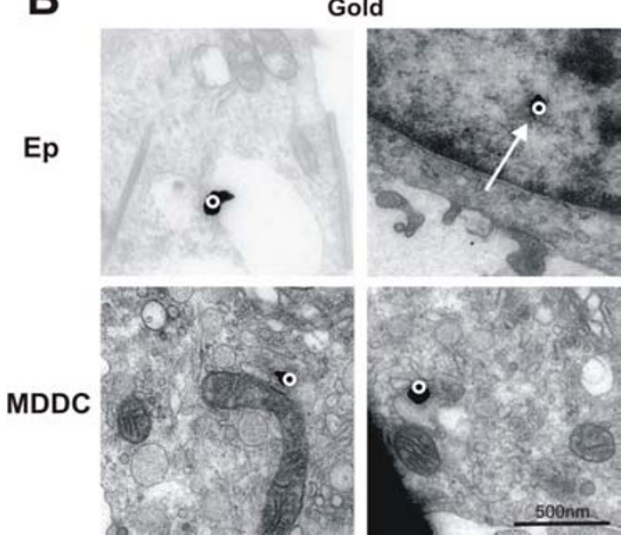

Figure 3

EELS images of cells containing $\mathrm{TiO}_{2}$ and silver enhanced gold particles. $\mathrm{TiO}_{2}$ particles $(\mathrm{A})$ were found inside all cell types, i.e. MDM, epithelial cells, and MDDC, as aggregates in vesicles (A, left panel), and as single particles or as small aggregates free in the cytoplasm ( $A$, right panel). Silver enhanced gold particles (B) were found in all three cell types as single particles or as small aggregates only free in the cytoplasm and even in the nucleus ( $B$, arrow). The circles mark the region where the element analysis was performed.

Some gold particles were even found in the cell nucleus (Fig. 3B arrow).

\section{Influence of particle size and composition on the inflammatory potential}

As shown above, the morphological examination of the particle-cell interactions showed that all particle types used in this study are able to enter the different cells of the co-culture system. Therefore, we determined the proinflammatory cytokine TNF- $\alpha$ in the culture supernatants after incubations with particles for $24 \mathrm{~h}$ (Fig. 4). In the control cultures minor TNF- $\alpha$ concentrations were measured. When LPS (lipopolysaccaride, a positive control) and $1 \mu \mathrm{m}$ particles were added to the cell cultures, the TNF- $\alpha$ signal increased significantly. No increase in TNF$\alpha$ concentration was seen when $0.078 \mu \mathrm{m}$ polystyrene particlesor $\mathrm{TiO}_{2} \mathrm{NP}$ were added to the cultures. We found a significant increase of TNF- $\alpha$ in the supernatants after applying gold NP.

\section{Discussion}

The understanding of the possible functional and pathological disorders induced in the respiratory tract by NP requires the investigation of the direct effects of these particles on state and activity of lung cells. Therefore, we have used our established in vitro model of the airway wall [37] to compare the translocation behaviors of fine particles and NP, to study the intracellular localization of NP and to investigate the potential of the particles in dependence on size and material to induce a pro-inflammatory response.

First, fine fluorescently labeled polystyrene particles (1 $\mu \mathrm{m})$ and NP $(0.078 \mu \mathrm{m})$ have been added to the cells and visualized by LSM combined with digital image restoration [25]. Both particle sizes were found in all three cell types, however, the number of particles was always considerably smaller in the epithelial cells than in both other cell types. Quantitative analysis revealed that the number

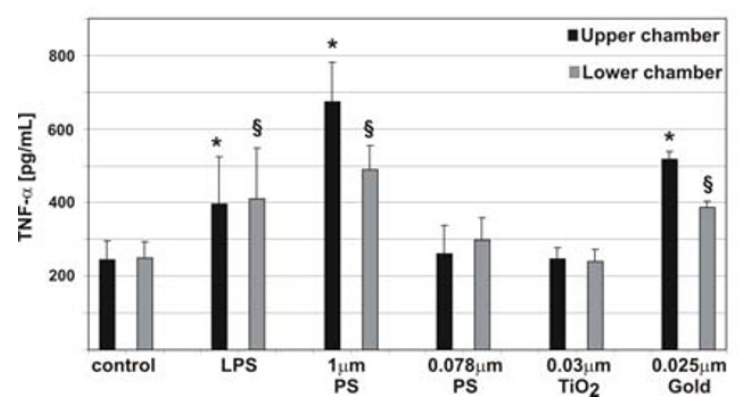

\section{Figure 4}

TNF- $\alpha$ release in triple cell co-cultures upon particle incubation. TNF- $\alpha$ levels in the supernatants (upper chamber, lower chamber) were measured by ELISA. TNF- $\alpha$ release in cells exposed to LPS, I $\mu \mathrm{m}$, and $0.078 \mu \mathrm{m}$ polystyrene particles, $\mathrm{TiO}_{2}$, and gold NP. Values are means \pm SD of 3 experiments. $*$ indicates a statistical difference to the levels in the supernatants in the control of the upper chamber, $\S$ indicates a statistical difference to the levels in the supernatants in the control of the lower chamber. 
Table I: Contingency table analysis of particle numbers in different cell types among the particle sizes

\begin{tabular}{lcccc}
\hline Cell type & $\begin{array}{c}\mathbf{P}_{\text {obs }}\left(\mathbf{P}_{\text {exp }}\right) \\
\mathbf{I m}\end{array}$ & $\begin{array}{c}\mathbf{P}_{\text {obs }}\left(\mathbf{P}_{\text {exp }}\right) \\
\mathbf{0 . 0 7 8} \boldsymbol{\mu m}\end{array}$ & Row total & $\mathbf{C h i}^{\mathbf{2}}$ \\
\hline AM & $190(216.7)$ & $\begin{array}{c}176.67 \\
(149.97)\end{array}$ & 366.67 & $\mathbf{3 . 2 9 ;} \mathbf{4 . 7 5}$ \\
Epithelial & 14.69 & $4.43(7.82)$ & 19.12 & $1.017 ; 1.47$ \\
cells & $(11.3)$ & & & \\
DC & 116.22 & $4 I(64.31)$ & 157.22 & $\mathbf{5 . 8 5} ; \mathbf{8 . 4 5}$ \\
$\begin{array}{l}\text { Column } \\
\text { total }\end{array}$ & $\begin{array}{c}(92.9) \\
(320.91\end{array}$ & $\begin{array}{c}222.1 \\
(222.1)\end{array}$ & 543.01 & $\mathbf{2 4 . 8 2 7}$ \\
\hline
\end{tabular}

In the first column, the different cell types, i.e. MDM, epithelial cells, or MDDC, are denoted. In each of the cell types, the mean number of particles was counted $\left(\mathrm{P}_{\text {obs }}\right)$. According to the equation given in the methods section the number of expected particles was calculated $\left(P_{\text {exp }}\right)$. To see whether the distribution of counted particles within the three cell types was different for the different particle sizes, partial chi ${ }^{2}$ values and total chi ${ }^{2}$ were calculated. For 2 degrees of freedom (3-I cell types $\times 2-1$ particle sizes) and with a total chi-squared value of 24.827 the null-hypothesis that the differently sized particles are similarly distributed among the different cells has to be rejected $(p<0.01)$. Those cell types and particle sizes that make a substantial contribution to the total chisquared (more than 10\%) are highlighted in bold letters within the table.

of $1 \mu \mathrm{m}$ and $0.078 \mu \mathrm{m}$ particles inside MDM was twice the number found in MDDC. This finding confirms what was reported by Kiama et al. [39] who showed that MDM are twice as phagocytic as immature MDDC in vitro. Only a small particle number was found inside epithelial cells for both particle sizes. The quantitative analysis for the NP distribution in the different cell types was performed as described by Mühlfeld et al. [40]. One main conclusion that can be drawn from this analysis is that the distribution of particles within the different cell types is not equal among the different particle sizes. The difference is characterized by a significant lower number of NP to be localized in the MDDC in comparison to the larger particles. Conversely, the number of particles localized in MDM was higher than expected for $0.078 \mu \mathrm{m} \mathrm{NP}$ and lower than expected for the larger particles. Recently, we have shown that MDDC and MDM collaborate as sentinels against fine particles by building a transepithelial interdigitating network of cell processes [41], so the current data underline that fine particles might actively be transported from MDM to MDDC, whereas the nano-sized material has different translocation characteristics. It is tempting to speculate that the unique entering mechanisms of NP may prevent the physiological interplay between macrophages and dendritic cells to a certain degree. Concluding from our results and from earlier published findings $[11,25]$ we confirmed the phagocytic uptake for $1 \mu \mathrm{m}$ particles whereas particles $<0.1 \mu \mathrm{m}$ may have the property of entering cells by unknown mechanisms (what we called adhesive

interaction).
All polystyrene particle types we used in this study were observed in MDDC in the triple cell co-culture system, although the MDDC, residing underneath the epithelial monolayer, were thought not to be directly exposed to particles. Since the TEER did not decrease during the experiment we assume that the tight junctions were not opened after addition of particles to the medium. However, our studies showed that MDDC formed fine cytoplasmic processes towards the luminal side or even migrated as complete cells to the apical side of the epithelial barrier wall to take up particles of a diameter of $1 \mu \mathrm{m}$ deposited on the epithelial apical surface [41]. However, it was the tightness of the epithelium which influenced the migration index of the MDDC, but not the mechanism of particle uptake [41]. Whether the cells are interacting in a similar manner after exposure of the cultures to $\mathrm{NP}$ is the aim of further investigations.

In order to draw any conclusions whether NP induce cellular responses it is indispensable to know if particles are attached to the cell membrane or have entered the cells. Sophisticated microscopic methods have been applied for the visualization of manufactured NP as described in Rothen-Rutishauser et al. [25]: LSM in combination with image restoration for fluorescently labeled polystyrene $\mathrm{NP}$, and EFTEM for gold NP as well as for $\mathrm{TiO}_{2} \mathrm{NP}$. As shown in LSM and TEM micrographs, polystyrene, gold and $\mathrm{TiO}_{2} \mathrm{NP}$ can enter cells, even the non-phagocytic A549 epithelial cells. This confirms previous reports that NP can enter many cell types $[11,42]$, even non-phagocytic cells like red blood cells which have neither phagocytic receptors at the surface nor are they equipped with a phagocytic apparatus [25]. For some NP the cell membrane does not seem to exert a barrier function; it seems as if they just pass through the membrane. We have currently no idea how these particles penetrate through the cell membrane. The entering mechanisms are currently under debate. Some assume these particles to enter cells by any endocytic processes other suggest mechanisms different from endocytosis like diffusion, membrane fluidity, passing through channels or further by adhesive interactions as for instance electrostatic forces, Van der Waals- or steric interactions $[11,43,44]$. Clearly, the entering mechanisms of NP need to be further investigated.

$\mathrm{TiO}_{2}$ was found inside all three cell types of the triple cell co-culture model, i.e. MDM, epithelial cells, and MDDC, as membrane-bound larger aggregates as well as free as smaller aggregates or individual particles in the cytoplasm. Other studies have shown vesicles containing mostly large aggregates of $\mathrm{TiO}_{2}$ in A549 cells [45] or membrane-bound ceria NP agglomerates in human lung fibroblasts [46]. However, in all these studies only conventional TEM was used to detect the particles, and it might well be that single NP or small aggregates of few 
particles could not be identified. In our study gold NP were detected only free in the cytoplasm of all cell types. These findings are in contrast to the study from Takenaka et al. [47] who detected gold NP aggregates inside small vesicles in macrophages of the rat lung. It is not clear why we could not detect vesicle containing gold particles, however, it might be that in the study from Takenaka et al. [47] single NP or small aggregates were not detectable by conventional TEM in the cytoplasm. We also found gold particles inside the cell nuclei. Penetration of NP into the nucleus has been shown in a number of studies $[11,27$ 29]. Tsoli and colleagues[28] have shown that $1.4 \mathrm{~nm}$ $\mathrm{Au}_{55}$ particle clusters interact with DNA in a way which may be the reason for the strong toxicity of these tiny particles towards human cancer, since it is generally known that DNA double-strand breaks may cause cancer [48]. Of great interest is the stereological analysis of $\mathrm{TiO}_{2}$ and gold $\mathrm{NP}$, which is planned in future studies.

A crucial reaction of cells to particles deposited in the lung is the release of cytokines from activated epithelial cells, MDM and MDDC. The essential role of the pro-inflammatory chemokine TNF- $\alpha$ in relation to lung injuries caused by ambient UFP or manufactured NP was described by Donaldson and colleagues [19]. In our studies TNF- $\alpha$ release after exposure to $1 \mu \mathrm{m}$ polystyrene particles was significantly higher than in cultures exposed to $0.078 \mu \mathrm{m}$ particles. Moreover, varying responses have been found with different types of NP, like polystyrene, gold, and $\mathrm{TiO}_{2}$ particles. Interestingly, only the exposure to gold NP was found to induce a pro-inflammatory response.

In conclusion, all particle types were detected inside the three cells of the triple cell co-culture model independent of their composing material and size. However, the distribution of fine and nano-sized polystyrene particles among the cells of the culture system was different suggesting size to be an important factor determining the translocation characteristics of particles. Additionally, the intracellular localization differed between $\mathrm{TiO}_{2}$ and gold NP suggesting different modes of intracellular trafficking and, possibly, entering mechanisms depending on the particle material. In accordance, both size and material of the particles affected the toxicological potential of the particles, i.e. the TNF- $\alpha$ generation. Whether the different inflammatory potential between differently composed NP is related to their entering mechanism and intracellular target structures needs further research.

\section{Methods \\ Triple cell co- cultures}

Cultures were prepared as previously described by Rothen-Rutishauser et al. [37]. Briefly, A549 cells (passage 10-40) were grown on cell culture inserts (surface area of $4.2 \mathrm{~cm}^{2}$, pores of $3.0 \mu \mathrm{m}$ in diameter, high pore density
PET membranes for 6-er well plates; (BD Biosciences, Basel, Switzerland). MDM and MDDC were derived from human blood monocytes as already described [37]. Briefly, peripheral blood monocytes were isolated from buffy coats (blood donation service, Berne, Switzerland) and cultured in the same medium as used for the epithelial cells except for the supplementation of 5\% human serum (blood donation service Bern, Switzerland) instead of $10 \%$ foetal calf serum. For the generation of MDDC the monocytes were cultured for 7-10 d in medium supplemented with $34 \mathrm{ng} / \mathrm{mL}$ IL-4 (Sigma, Fluka Chemie GmbH, Buchs, Switzerland) and with $50 \mathrm{ng} / \mathrm{mL}$ GM-CSF (R\&D Systems, Oxon, UK), whereas the MDM were obtained without any additional supplements for 7-10d. Epithelial cells were cultured for 7 days before MDM were added on top of the epithelial monolayer and MDDC underneath the insert membrane. The triple cell co-cultures were kept overnight in medium supplemented with $1 \%$ L-Glutamine, $1 \%$ penicillin/streptomycin, and 5\% heat inactivated (pooled) human serum at $37^{\circ} \mathrm{C}$ in $5 \%$ $\mathrm{CO}_{2}$ humidified atmosphere.

\section{Particle incubation}

Commercially available particles were used: Fluoresbrite ${ }^{\mathrm{TM}}$ plain yellow green microspheres with diameters of $1 \mu \mathrm{m}$ (Polysciences, Chemie Brunschwig AG, Basel, Switzerland); Fluorescent particles, yellow green with a mean diameter of $0.078 \mu \mathrm{m}$ (KiskerGbR, Chemie Brunschwig AG, Basel, Switzerland); Bovine Serum Albumin (BSA) gold tracers with a diameter of $0.025 \mu \mathrm{m}$ (Aurion, Anawa Trading SA, Wangen, Switzerland); Titanium (IV) oxide $\left(\mathrm{TiO}_{2}\right)$, anatase $99.9 \%$ (metal basis)) with a mean diameter of 0.02-0.03 $\mu \mathrm{m}$ (Alfa Aesar, Johnson Matthey GmbH, Karlsruhe, Germany).

All particle dilutions were sonicated for 2 min prior to incubation with cells in order to avoid aggregation. Polystyrene particles were diluted in RPMI 1640 medium and adjusted to a concentration of $10^{10}$ particles $/ \mathrm{mL}$. As recommended from the company gold particles were first dialyzed in PBS for 24 hours to remove the sodium acid and were diluted in RPMI 1640 to a final dilution of $10^{10}$ particles $/ \mathrm{mL}$. A stock solution of $\mathrm{TiO}_{2}$ particles in millipore water $(2.5 \mathrm{mg} / \mathrm{mL})$ was diluted in RPMI 1640 to a final concentration of $5 \mu \mathrm{g} / \mathrm{mL}$. One $\mathrm{mL}$ of this suspension was then added to cell cultures. Incubations were done for $24 \mathrm{~h}$ before analysis of the cells. Each experiment was repeated between 3 to 5 times.

\section{TEER measurements}

TEER was measured with the Millicell-ERS system (MERS 000 01, Millipore AG, Volketswil, Switzerland). The mean of 3 measurements per insert was determined. The electrical resistance of filters without cells was subtracted from all samples and the resistance values were multiplied with 
the surface area of the inserts $\left(4.2 \mathrm{~cm}^{2}\right)$. Electrical resistance was measured in triple cultures to follow the epithelial tightness as described in Rothen-Rutishauser et al. [49].

\section{Cell labeling and fixation}

Cells were washed in phosphate buffered saline (PBS, 10 $\mathrm{mM}, \mathrm{pH}$ 7.4: $130 \mathrm{mM} \mathrm{NaCl}, \mathrm{Na}_{2} \mathrm{HPO}_{4}, \mathrm{KH}_{2} \mathrm{PO}_{4}$ ) and fixed for $15 \mathrm{~min}$. at room temperature in 3\% paraformaldehyde in PBS. Fixed cells were treated with $0.1 \mathrm{M}$ glycine in PBS for $5 \mathrm{~min}$. and permeabilized in $0.2 \%$ Triton X-100 in PBS for $15 \mathrm{~min}$. The cells were incubated with the first and second antibodies for $60 \mathrm{~min}$ each at room temperature. Preparations were mounted in PBS:glycerol (2:1) containing $170 \mathrm{mg} / \mathrm{mL}$ Mowiol 4-88 (Calbiochem, VWR International $\mathrm{AG}$ ).

Antibodies were diluted in PBS as follows: mouse antihuman CD14 1:20 (Clone UCHM-1, C 7673, Sigma), mouse anti-human CD86 1:20 (Clone HB15e, 36931A, PharMingen, BD Biosciences, ), goat anti-mouse cyanine 5 1:50 (AP124S, Chemicon, VWR International AG, Life Sciences, Lucerne, Switzerland), and phalloidin rhodamine 1:100 (R-415, Molecular Probes, Invitrogen AG, Basel, Switzerland).

\section{Tumor necrosis factor alpha detection}

Following particle incubation, supernatants from triple cell co-cultures in the upper and lower chamber were collected separately and stored at $-70^{\circ} \mathrm{C}$. After centrifugation, TNF- $\alpha$ was quantified by a commercially available DuoSet ELISA Development kit (R\&D Systems, Catalogue Number: DY 210, Oxon, UK) according to the manufacturer's recommendations. The assay was repeated twice, each in duplicates. Between three to five experiments were carried out for each combination of particles and cell types. The incubation time of the cells with the particle suspension was $24 \mathrm{~h}$.

The mouse anti-human TNF- $\alpha$ capture antibody was coated overnight in 96-well immunoassay plates (NUNC, MaxiSorp) at a concentration of $4 \mu \mathrm{g} / \mathrm{mL}$ in PBS at room temperature. Differing to the producer's protocol the plate was blocked with PBS supplemented with 1\% BSA, 5\% sucrose and $0.05 \%$ sodium acid for $1 \mathrm{~h}$ at room temperature (as opposed to the reagent dilution provided with the test kit). After washing with buffer, supernatants from samples and the standards (recombinant human TNF- $\alpha$, concentrations from 0.02 to $10 \mathrm{ng} / \mathrm{mL}$ of TNF- $\alpha$ ) were pipetted into the wells and incubated at room temperature for $2 \mathrm{~h}$. After washing, biotinylated goat anti-human TNF- $\alpha$ detection antibodies were added to the wells and incubated for $2 \mathrm{~h}$ at room temperature. After washing, horseradish peroxidase conjugated streptavidin was added to the plates, which were then incubated for $20 \mathrm{~min}$ at room temperature in the dark. Finally, the substrate solution (Tetramethylbenzidine $/ \mathrm{H}_{2} \mathrm{O}_{2}$ (R\&D Systems, Art.Nr. DY999)) was added. After $20 \mathrm{~min}$ in darkness, the colour development was stopped by $2 \mathrm{NH}_{2} \mathrm{SO}_{4}$ and the plate was put on the shaker for $10 \mathrm{~min}$ (differing from the protocol). Then the absorbance was read at $450 \mathrm{~nm}$ using an ELISA reader (SpectraMax 340 PC or Benchmark Plus Microplate Spectrophotometer (BioRad, Hempel Hempstead, UK)). The concentration of TNF- $\alpha$ was determined by comparing the absorbance of the samples with standard recombinant human TNF- $\alpha$ and calculated with the Office Excel program from Microsoft.

\section{Laser scanning microscopy and image restoration}

A Zeiss LSM 510 Meta with an inverted Zeiss microscope (Axiovert 200 M, Lasers: HeNe 633 nm, HeNe 543 nm, and $\operatorname{Ar} 488 \mathrm{~nm}$ ) was used. Image processing and visualization was performed using IMARIS, a 3D multi-channel image processing software for confocal microscopic images (Bitplane AG, Zurich, Switzerland). For the localization and visualization of particles at high resolution a deconvolution algorithm was applied [25] using the Huygens 2 software (Scientific Volume Imaging B. V., Hilversum, Netherlands) in order to increase axial and lateral resolutions and to decrease noise.

\section{Particle quantification}

After the image acquisition the total particle number in the scans was counted with the particle tracking software Diacount (Semasopht, Lausanne, Switzerland; http:// www.semasopht.com). For each experimental sample cells were randomly scanned with LSM. Experiments were performed in triplicates or quadruplicates, and 10-15 cells were scanned for each data point. The particles were counted within individually defined cell types, which were labelled for specific cell surface markers (CD14 for MDM, and CD86 for MDDC, F-Actin for the epithelial cells).

\section{Energy filtering transmission electron microscopy}

EFTEM analysis was performed as described in RothenRutishauser et al. [25]. Briefly, cells were fixed with $2.5 \%$ glutaraldehyde in $0.03 \mathrm{M}$ potassium phosphate buffer, $\mathrm{pH}$ 7.4. The cells were postfixed with $1 \%$ osmium tetroxide in $0.1 \mathrm{M}$ sodium cacodylate buffer, and with $0.5 \%$ uranyl acetate in $0.05 \mathrm{M}$ maleate buffer. Cells were then dehydrated in a graded series of ethanol and embedded in Epon. Ultrathin $(\leq 50 \mathrm{~nm})$ sections were cut, mounted onto uncoated 600-mesh copper grids, and stained with uranyl acetate and lead citrate. The presence and localization of $\mathrm{TiO}_{2}$ particles was investigated with a LEO 912 transmission electron microscope (Zeiss, Oberkochen, Germany) using electron energy loss spectroscopy. Since gold was not suitable for elemental analysis the gold particles were coated with silver using silver enhancement 
reagent (AURION R-GENT SE-LM; Aurion, Anawa trading SA).

\section{Statistics}

The results of the TEER and the ELISA measurements are expressed as mean values with the standard deviation of the mean (SD). The statistical analysis was performed using SigmaStat for Windows (Version 3.10, Systat Software, Inc., Richmond, California, USA) statistical software. Two groups were compared using Student's t-Test. p $<0.05$ was considered to be significant.

The distribution of the different particles among the different cell types was compared using a contingency table analysis as described by Mühlfeld et al. [40]. The observed numbers of polystyrene particles were compared by use of a contingency table analysis to depict changes in particle distribution among the different cell types according to the size group of the particles. From the number of observed particles, the number of expected particles was calculated according to the equation: column total $\mathrm{x}$ row total/grand total $=$ expected number of particles. Partial chi-squared values for each cell type and particle size are given by: (observed particles - expected particles) ${ }^{2} /$ expected particles $=$ partial chi squared value. From the partial chi squared values the total chi squared value was calculated by summing up the partial values. The total chi squared value indicated whether the distributions of particles among the different cell types differed depending on particle size. The partial chi squared values helped to identify those compartments that contributed substantially to the different distributions. A convenient cut-off value for a substantial contribution is given by $10 \%$ or more of the total chi-squared.

\section{List of abbreviations}

BSA Bovine serum albumin

EFTEM Energy filtering transmission electron microscopy

LSM Laser scanning microscopy

MDDC Monocyte derived dendritic cells

MDM Monocyte derived macrophages

NP Nanoparticles

PBS Phosphate buffered saline

$\mathrm{TiO}_{2}$ Titanium dioxide

TEM Transmission electron microscopy

TNF- $\alpha$ Tumour necrosis factor alpha
UFP Ultrafine particles

\section{Competing interests}

The author(s) declare that they have no competing interests.

\section{Authors' contributions}

BRR carried out the design of the study, has done the acquisition of the data, the analysis and interpretation of data, and drafted the manuscript. ChM has performed the contingency table analysis; he has been involved in the analysis and interpretation of data, as well as drafting the manuscript. FB has been involved in the analysis and interpretation of data, and in revising the manuscript critically for important intellectual content. CM has performed the ELISA measurements and has done the data analysis. PG was the project leader, he has intellectually accompanied the experimental work; he has been involved in revising the manuscript critically for important intellectual content and has given final approval of the version to be published.

\section{Acknowledgements}

We are grateful to Barbara Tschirren, Andrea Stokes, Claudia Haller, Beat Haenni and Sandra Frank for their excellent technical assistance.

This work was supported by the Swiss National Science Foundation, the Swiss Agency for the Environment, the Silva Casa and the Johanna

Dürmüller-Bol Foundation.

\section{References}

I. Mazzola L: Commercializing nanotechnology. Nat Biotechnol 2003, 21 : II37-II 43.

2. Paull $R$, Wolfe J, Hebert $P$, Sinkula M: Investing in nanotechnology. Nat Biotechnol 2003, 2 I: I I 44- I 47.

3. Gwinn MR, Vallyathan V: Nanoparticles: Health Effects-Pros and Cons. Environ Health Perspect 2006, I | 4: 1818-1825.

4. Moghimi SM, Hunter AC, Murray JC: Nanomedicine: current status and future prospects. FASEB J 2005, 19:3 II-330.

5. Maynard A, Michelson E: The Nanotechnology Consumer Products Inventory. 2005 [http://www.nanotechproject.org/ index.php?id=44].

6. Nicod LP: Lung defenses: an overview. Eur Respir Rev 2005, 95:45-50.

7. Gehr P, Bachofen M, Weibel ER: The normal human lung: ultrastructure and morphometric estimation of diffusion capacity. Respir Physiol 1978, 32:121-I40.

8. Peters A, Wichmann HE, Tuch T, Heinrich J, Heyder J: Respiratory effects are associated with the number of ultrafine particles. Am J Respir Crit Care Med 1997, 155:1376-1383.

9. Wichmann HE, Spix C, Tuch T, Wolke G, Peters A, Heinrich J, Kreyling WG, Heyder J: Daily mortality and fine and ultrafine particles in erfurt, germany part I: role of particle number and particle mass. Res Rep Health Eff Inst 2000, 98:5-86.

10. Schulz H, Harder V, Ibald-Mulli A, Khandoga A, Koenig W, Krombach F, Radykewicz R, Stampfl A, Thorand B, Peters A: Cardiovascular effects of fine and ultrafine particles. J Aerosol Med 2005, 18:1-22.

II. Geiser M, Rothen-Rutishauser B, Kapp N, Schurch S, Kreyling W, Schulz H, Semmler M, Im Hof V, Heyder J, Gehr P: Ultrafine particles cross cellular membranes by nonphagocytic mechanisms in lungs and in cultured cells. Environ Health Perspect 2005, I I3:|555-I560.

12. Mühlfeld CH, Geiser M, Kapp N, Gehr P, Rothen-Rutishauser B: Reevaluation of pulmonary titanium dioxide nanoparticle distribution using the "relative deposition index": Evidence for 
clearance through microvasculature. Particle Fibre Toxicol 2007 in press.

13. Brown JS, Zeman KL, Bennett WD: Ultrafine particle deposition and clearance in the healthy and obstructed lung. Am J Respir Crit Care Med 2002, 166: I240-1247.

14. Kreyling WG, Semmler M, Erbe F, Mayer P, Takenaka S, Schulz H, Oberdorster G, Ziesenis A: Translocation of ultrafine insoluble iridium particles from lung epithelium to extrapulmonary organs is size dependent but very low. J Toxicol Environ Health $A$ 2002, 65:1513-1530.

15. Oberdoerster G, Sharp Z, Atudorei V, Elder A, Gelein R, Kreyling W, Cox C: Translocation of inhaled ultrafine particles to the brain. Inhal Toxicol 2004, 16:437-445.

16. Pope CA III, Dockery DW, Schwartz J: Review of epidemiological evidence of health effects of particulate air pollution. Inhal Toxicol 1995, 7:I-18.

17. Lighty JS, Veranth JM, Sarofim AF: Combustion aerosols: factors governing their size and composition and implications to human health. J Air Waste Manag Assoc 2000, 50:1565-1618.

18. Borm PJ, Kreyling W: Toxicological hazards of inhaled nanoparticles - potential implications for drug delivery. J Nanosci Nanotechnol 2004, 4:52I-53I.

19. Donaldson K, Tran L, Jimenez LA, Duffin R, Newby DE, Mills N, MacNee W, Stone V: Combustion-derived nanoparticles: a review of their toxicology following inhalation exposure. Part Fibre Toxicol 2005, 2:10.

20. Nel A, Xia T, Madler L, Li N: Toxic potential of materials at the nanolevel. Science 2006, 3 I I:622-627.

21. Oberdoerster G, Oberdoerster E, Oberdoerster J: Nanotoxicology: an emerging discipline evolving from studies of ultrafine particles. Environ Health Perspect 2005, I I 3:823-839.

22. Kreyling WG, Semmler-Behnke M, Moller W: Ultrafine particlelung interactions: does size matter? J Aerosol Me 2006, 19:74-83.

23. Foged C, Brodin B, Frokjaer S, Sundblad A: Particle size and surface charge affect particle uptake by human dendritic cells in an in vitro model. Int J Pharm 2005, 298:3 I5-322.

24. Kapp N, Kreyling W, Schulz H, Im Hof V, Gehr P, Semmler M, Geiser $M$ : Electron energy loss spectroscopy for analysis of inhaled ultrafine particles in rat lungs. Microsc Res Tech 2004, 63:298-305.

25. Rothen-Rutishauser BM, Schürch S, Haenni B, Kapp N, Gehr P: Interaction of fine and nanoparticles with red blood cells visualized with advanced microscopic techniques. Environ Sci Technol 2006, 40:4353-4359.

26. Li N, Sioutas C, Cho A, Schmitz D, Misra C, Sempf J, Wang M, Oberley $T$, Froines J, Nel $A$ : Ultrafine particulate pollutants induce oxidative stress and mitochondrial damage. Environ Health Perspect 2003, I I I:455-460.

27. Gurr JR, Wang AS, Chen $\mathrm{CH}$, Jan $\mathrm{KY}$ : Ultrafine titanium dioxide particles in the absence of phopactivation can induce oxidative DNA damage to human bronchial epithelial cells. Toxicol 2005, I 5:66-73.

28. Tsoli M, Kuhn H, Brandau W, Esche H, Schmid G: Cellular uptake and toxicity of $\mathrm{Au}_{55}$ clusters. Small 2005, 8-9:84I-844.

29. Liu Y, Meyer-Zalka W, Franzka S, Schmid G, Leis M, Kuhn H: GoldCluster Degradation by the Transition of B-DNA into ADNA and the Formation of Nanowires. Angew Chem Int Ed 2003, 42:2853-2857.

30. Muller J, Huaux F, Moreau N, Misson P, Heilier J-F, Delos M, Arras M, Fonseca A, Nagy JB, Lison D: Respiratory toxicity of multi-wall carbon nanotubes. Toxicol Appl Pharmacol 2005, 207:22I-23I.

31. Gonzalez-Flecha B: Oxidant mechanisms in response to ambient air particles. Mol Aspects Med 2004, 25:169-182.

32. Vinzents PS, Møller P, Sørensen M, Knudsen LE, Hertel O, Jensen FP, Schibye B, Loft S: Personal exposure to ultrafine particles and oxidative DNA damage. Environ Health Perspect 2005, I I 3: 1485-1490.

33. Rahman I, MacNee W: Role of transcription factors in inflammatory lung diseases. Thorax 1998, 53:60I-612.

34. Brown DM, Wilson MR, MacNee W, Stone V, Donaldson K: Sizedependent proinflammatory effects of ultrafine polystyrene particles: a role for surface area and oxidative stress in the enhanced activity of ultrafines. Toxicol Appl Pharmacol 200I, 175:191-199.

35. Pope CA III, Burnett RT, Thurston GD, Thun MJ, Calle EE, Krewski $D$, Godleski JJ: Cardiovascular mortality and long-term expo- sure to particulate air pollution: epidemiological evidence of general pathophysiological pathways of disease. Circulation 2004, 109:7I-77.

36. Brown DM, Donaldson K, Borm PJ, Schins RP, Dehnhardt M, Gilmour $P$, Jimenez LA, Stone V: Calcium and ROS-mediated activation of transcription factors and TNF-alpha cytokine gene expression in macrophages exposed to ultrafine particles. Am J Physiol Lung Cell Mol Physiol 2004, 286:L344-L353.

37. Rothen-Rutishauser BM, Kiama SG, Gehr P: A three-dimensional cellular model of the human respiratory tract to study the interaction with particles. Am J Respir Cell Mol Biol 2005, 32:28I-289.

38. Daniel MC, Astruc D: Gold Nanoparticles: Assembly, Supramolecular Chemistry, Quantum-Size-Related Properties, and Applications toward Biology, Catalysis, and Nanotechnology. Chem Rev 2004, 104:293-346.

39. Kiama SG, Cochand L, Karlsson L, Nicod LP, Gehr P: Evaluation of phagocytic activity in human monocyte-derived dendritic cells. J Aerosol Med 200I, 14:289-299.

40. Mühlfeld Ch, Mayhew TM, Gehr P, Rothen-Rutishauser B: A novel quantitative method for analysing the distribution of nanoparticles between different tissue and intracellular compartments. A AerosolMed in press.

4I. Blank F, Rothen-Rutishauser B, Gehr P: Dendritic cells and macrophages form a transepithelial network against foreign particulate antigens. Am J Respir Cell Mol Biol 2007, 36:669-77.

42. Wottrich R, Diabate S, Krug HF: Biological effects of ultrafine model particles in human macrophages and epithelial cells in mono- and co-culture. Int J Hyg Environ Health 2004, 207:353-36I.

43. Rimai DS, Quesnel DJ, Busnaia AA: The adhesion of dry particles in the nanometer to micrometer-size range. Colloids and Surfaces A. Physicochemical and Engineering aspects 2000, 165:3-10.

44. Rothen-Rutishauser B, Schurch S, Gehr P: Interaction of particles with membranes. In The toxicology of particles Edited by: Donaldson K, Borm P. CRC Press LCC; 2007:139-160.

45. Stearns RC, Paulauskis JD, Godleski JJ: Endocytosis of ultrafine particles by A549 cells. Am J Respir Cell Mol Biol 200I, 24: I08-II5.

46. Limbach LK, Li Y, Grass RN, Brunner TJ, Hintermann MA, Muller M, Gunther D, Stark W]: Oxide nanoparticle uptake in human lung fibroblasts: effects of particle size, agglomeration, and diffusion at low concentrations. Environ Sci Technol 2005, 39:9370-9376.

47. Takenaka S, Karg E, Kreyling WG, Lentner B, Moller W, BehnkeSemmler M, Jennen L, Walch A, Michalke B, Schramel P, Heyder J, Schulz $\mathrm{H}$ : Distribution pattern of inhaled ultrafine gold particles in the rat lung. Inhal Toxicol 2006, 18:733-740.

48. Agarwal S, Tafel AA, Kanaar R: DNA double-strand break repair and chromosome translocations. DNA Repair (Amst) 2006, 5:1075-108I.

49. Rothen-Rutishauser B, Riesen FK, Braun A, Gunthert M, WunderliAllenspach $\mathrm{H}$ : Dynamics of tight and adherens junctions under EGTA treatment. J Membr Biol 2002, 188:151-162.

Publish with Bio Med Central and every scientist can read your work free of charge

"BioMed Central will be the most significant development for disseminating the results of biomedical research in our lifetime. "

Sir Paul Nurse, Cancer Research UK

Your research papers will be:

- available free of charge to the entire biomedical community

- peer reviewed and published immediately upon acceptance

- cited in PubMed and archived on PubMed Central

- yours - you keep the copyright 